\title{
PERANAN BENEFITS, TRUST SERTA EASE OF USE TERHADAP USAGE INTENTION PADA SEKTOR E-PAYMENT DI JABODETABEK
}

\author{
Lilis Susilawaty $^{1}$, Nicholas Wilson ${ }^{2 *}$ \\ ${ }^{1}$ Fakultas Ilmu Sosial dan Humaniora, Program Studi Manajemen, Universitas Bunda Mulia, Jakarta \\ Email: lsusilawaty@bundamulia.ac.id \\ ${ }^{2}$ Fakultas Ilmu Sosial dan Humaniora, Program Studi Manajemen, Universitas Bunda Mulia, Jakarta \\ Email: nicholaswilson8989@gmail.com \\ *penulis korespondensi
}

\begin{abstract}
ABSTRAK
Penelitian ini dilakukan guna mengetahui dampak yang diberikan oleh benefits, trust, serta ease of use di dalam meningkatkan intensi konsumen untuk menggunakan berbagai layanan ataupun aplikasi $e$-payment yang ada sebagai media pembayaran utama yang konsumen gunakan sehari-hari. Adapun penelitian ini sendiri menggunakan kuesioner sebagai instrumen pengumpulan data yang disebarkan kepada 180 responden yang berpartisipasi pada penelitian ini. Adapun setelah dilakukan proses pengecekan dan validasi terkait dengan data yang telah diisi oleh seluruh responden, maka dapat disimpulkan bahwa seluruh data yang telah terkumpul merupakan data yang valid, reliable, serta dapat digunakan guna dianalisis pada penelitian ini. Seluruh data yang telah terkumpul selanjutnya dianalisis dengan menggunakan metode PLS-SEM. Berdasarkan pada hasil pengolahan data yang telah diperoleh, peneliti dapat menyimpulkan bahwa ketiga variabel independen, yaitu benefits, trust serta ease of use memiliki peranan yang signifikan di dalam mempengaruhi intensi konsumen untuk menggunakan aplikasi $e$-payment sebagai media pembayaran utama atas berbagai aktivitas pembelian ataupun aktivitas transaksi yang dilakukan.
\end{abstract}

Kata Kunci: Benefits, Trust, Ease of Use, Usage Intention, E-Payment Sector

\section{ABSTRACT}

This study was conducted in order to determine the impact which were given by several factors, such as benefits, trust and ease of use, on consumers' intention to choose and use e-payment services as their main payment method when consumers are buying or making any purchasing activities on any goods or services that consumers would like to buy. A total of 180 respondents participated in this study, in which, questionnaires were used as the main instrument for collecting all of the data needed from the respondents. All of the collected data then were analyzed using PLS-SEM method, in which, based on the results of the data analysis, authors would like to conclude that all of these factors, which are benefits, trust and ease of use, play an important and significant role in affecting consumers' intention in choosing and using e-payment services when consumers are buying products or services that they want to buy.

Keywords: Benefits, Trust, Ease of Use, Usage Intention, E-Payment Sector

\section{PENDAHULUAN}

\section{Latar Belakang}

Dalam kurun waktu kurang lebih 3-4 tahun terakhir, sektor ataupun industri e-payment dapat dikatakan sebagai salah satu sektor yang mengalami pertumbuhan ataupun perkembangan paling pesat dibandingkan dengan sektor ataupun industri lainnya di Indonesia (midtrans.com, 2020). Fenomena ini sendiri dapat dilihat dari semakin bertambahnya jumlah transaksi yang dihasilkan dari industri e-payment yang ada di Indonesia dalam rentang waktu tersebut. Berdasarkan data yang dipublikasikan oleh laman m2insights (m2insights.com, 2020), jumlah transaksi yang dihasilkan dari sektor e-payment di Indonesia telah mengalami peningkatan yang cukup signifikan, yang dimana, terjadi peningkatan dari dari total nilai transaksi sebesar 3.2 miliar dolar Amerika Serikat pada tahun 2018, menjadi 10.45 miliar dolar Amerika Serikat pada tahun 2019. Adapun masih berdasarkan pada sumber yang sama, total ataupun jumlah nilai transaksi yang dihasilkan dari sektor e-payment di Indonesia ini pun diprediksi akan mengalami peningkatkan 
ke angka 40 miliar dolar Amerika Serikat pada tahun 2025. Adapun berbagai data yang dipublikasikan ini pun menunjukkan betapa pesatnya pertumbuhan ataupun perkembangan sektor e-payment di Indonesia (m2insights.com, 2020).

Selain itu, selain dapat dilihat dari peningkatkan jumlah transaksi yang dihasilkan dari sektor $e$ payment ini dari tahun ke tahun, pertumbuhan serta perkembangan pesat yang terjadi pada sektor e-payment di Indonesia ini pun juga dapat dilihat dari semakin bertambahnya jumlah perusahaan yang menyediakan layanan e-payment ini dari waktu ke waktu, seperti GO-JEK (melalui layanan GO-PAY nya), OVO, LinkAja, ShopeePay, DANA, Sakuku, serta Jenius. Adapun jumlah perusahaan ini diprediksi akan terus bertambah dari tahun ke tahun, mengingat bahwa pada awalnya, ketika sektor e-payment ini pertama kali masuk ke Indonesia, hanya ada 2 (dua) perusahaan saja yang menyediakan layanan e-payment ini di Indonesia, yaitu OVO serta GOPAY. Peningkatan ataupun penambahan jumlah perusahaan ataupun aplikasi e-payment di Indonesia ini semakin menunjukkan bahwa bukan saja Indonesia berhasil menjelma sebagai salah satu negara dengan potensi pasar terbesar di kawasan Asia Tenggara untuk sektor $e$ payment ini, namun juga berhasil menjelma sebagai salah satu negara dengan tingkat pertumbuhan sektor e-payment paling pesat di dunia.

Selanjutnya, masih terkait dengan perkembangan serta pertumbuhan sektor e-payment di Indonesia ini, hal lainnya (selain peningkatan jumlah perusahaan yang menyediakan jasa ataupun layanan e-payment di Indonesia) yang turut mendorong perkembangan ataupun pertumbuhan pesat sektor e-payment di Indonesia ini adalah peningkatan jumlah masyarakat ataupun konsumen yang menggunakan berbagai aplikasi e-payment yang tersedia di pasaran. Sebagai contoh, dari tahun ke tahun, jumlah pengguna aplikasi e-payment di Indonesia cenderung mengalami peningkatan yang cukup signifikan. Adapun beberapa hal ataupun beberapa faktor yang mampu mendorong banyaknya serta meningkatnya jumlah masyarakat Indonesia yang mau dan ingin untuk mengadopsi serta menggunakan layanan e-payment ini diantaranya adalah berbagai keuntungan yang dapat diperoleh konsumen ketika menggunakan layanan e-payment ini (benefits), kepercayaan konsumen terhadap sistem platform serta perusahaan yang menyediakan layanan e-payment tersebut (trust), serta kemudahan yang konsumen rasakan ketika menggunakan layanan ataupun aplikasi e-payment ini (ease of use). Adapun secara bersama-sama, ketiga faktor ataupun variabel inilah yang dapat mempengaruhi intensi konsumen ataupun intensi masyarakat Indonesia di dalam mengadopsi ataupun menggunakan jasa ataupun layanan e-payment sebagai media pembayaran utama yang digunakan konsumen ketika akan melakukan pembelian suatu produk ataupun jasa dari sebuah perusahaan.

Benefits sendiri dapat dipahami sebagai persepsi ataupun penilaian pribadi konsumen terkait dengan berbagai keuntungan yang dapat dirasakan ataupun diperoleh konsumen ketika konsumen menggunakan suatu produk, jasa, sistem, teknologi ataupun aplikasi yang dikembangkan dan ditawarkan oleh suatu perusahaan. Adapun konsepsi dasar dari benefits ini berhubungan erat dengan konsepsi dasar dari value di dalam ranah pemasaran, yang dimana, setiap konsumen cenderung hanya akan membeli serta menggunakan produk ataupun jasa yang ditawarkan oleh perusahaan apabila berbagai keuntungan yang konsumen peroleh ataupun rasakan (benefits) melebihi ataupun lebih besar dibandingkan dengan biaya (costs) yang harus konsumen keluarkan guna memperoleh produk ataupun jasa tersebut. Dengan demikian, maka konsepsi dasar dari benefits ini penting untuk dapat dipahami secara mendalam oleh setiap perusahaan, mengingat bahwa kegagalan perusahaan di dalam menciptakan produk ataupun jasa yang mampu menawarkan berbagai keuntungan bagi para konsumen ataupun masyarakat dapat berakibat pada menurunnya (atau bahkan hilangnya) intensi konsumen di dalam membeli serta 
menggunakan produk ataupun jasa tersebut. Adapun terkait dengan konsepsi dasar dari $e$ payment ini sendiri, terdapat berbagai benefits ataupun keuntungan yang konsumen dapat peroleh ketika konsumen menggunakan layanan ataupun aplikasi e-payment ini, diantaranya adalah waktu transaksi yang lebih cepat, sistem transaksi yang lebih efisien, serta praktis (mengingat bahwa dengan adanya layanan ataupun aplikasi e-payment ini, konsumen tidak perlu lagi membawa uang tunai kemanapun mereka pergi). Berbagai keuntungan ini sendiri tidak dapat diperoleh konsumen apabila konsumen berbelanja ataupun membayar dengan menggunakan uang tunai sebagai sistem pembayaran tradisional. Beberapa keuntungan inilah yang cenderung mendorong banyaknya masyarakat Indonesia yang mengadopsi ataupun menggunakan layanan e-payment ini.

Selain itu juga, selain benefits, trust serta ease of use juga memegang peranan penting di dalam menentukan serta mempengaruhi intensi konsumen ataupun masyarakat Indonesia untuk mau mengadopsi serta menggunakan layanan e-payment yang tersedia di pasaran. Adapun trust ini sendiri dapat dipahami sebagai tingkat kepercayaan yang konsumen rasakan terhadap suatu sistem, produk, jasa ataupun perusahaan yang menyediakan jasa tersebut. Ketika kepercayaan konsumen terhadap suatu perusahaan cenderung lemah, maka hal ini dapat mengurangi minat konsumen di dalam menggunakan ataupun membeli berbagai produk ataupun jasa yang ditawarkan oleh perusahaan tersebut. Adapun terkait dengan konsepsi dasar dari sektor $e$ payment ini, trust tentu memiliki keterkaitan yang kuat di dalam menentukan apakah konsumen akan menggunakan layanan e-payment yang dikembangkan oleh suatu perusahan atau tidak, mengingat bahwa konsumen diharuskan untuk memberikan berbagai data yang bersifat personal kepada pihak perusahaan ketika pertama kali konsumen menggunakan layanan tersebut. Berkaitan dengan hal ini, maka tentunya konsumen harus memiliki kepercayaan (trust) yang kuat bahwa pihak perusahaan tidak akan menyalahgunakan seluruh data yang diberikan oleh konsumen. Adapun ketika rasa kepercayaan ini timbul dalam diri konsumen, maka barulah kemudian intensi konsumen untuk mengadopsi serta menggunakan berbagai layanan e-payment yang ditawarkan oleh suatu perusahaan muncul. Dengan demikian, maka penting bagi perusahaan untuk dapat mengembangkan suatu layanan e-payment yang bukan saja memiliki berbagai fitur canggih yang dapat memberikan berbagai benefits ataupun keuntungan bagi para penggunanya, namun juga bahwa layanan ataupun teknologi e-payment yang perusahaan tersebut kembangkan ini juga harus mampu meyakinkan konsumen bahwa seluruh data serta aktivitas transaksi yang konsumen lakukan tidak akan disalahgunakan oleh pihak perusahaan untuk kepentingan apapun.

Berikutnya, aspek ataupun faktor ease of use dari suatu sistem e-payment juga dapat menentukan sejauh ataupun seberapa kuat intensi yang dimiliki oleh setiap konsumen di dalam mengadopsi serta menggunakan teknologi yang dikembangkan oleh suatu perusahaan. Adapun ease of use ini dapat dipahami sebagai persepsi ataupun penilaian konsumen terkait dengan sejauh mana suatu teknologi ataupun sistem yang baru dapat dipelajari serta digunakan oleh konsumen dalam waktu yang singkat. Dengan kata lain, maka konsepsi dasar dari ease of use ini sendiri dapat dipahami sebagai sebuah konsep yang mampu menjelaskan perihal apakah konsumen memerlukan waktu yang panjang di dalam mempelajari serta menggunakan suatu layanan ataupun sistem yang dikembangkan oleh suatu perusahaan, ataukah konsumen memerlukan waktu yang lama guna mempelajari suatu sistem yang baru saja diciptakan oleh pihak perusahaan, yang dimana, kedua pertanyaan ini memiliki keterkaitan yang erat dengan konsepsi dasar dari ease of use ini sendiri. Hal ini dikarenakan apabila konsumen ataupun masyarakat merasa bahwa dibutuhkan waktu yang lama serta proses yang kompleks di dalam mempelajari suatu sistem ataupun teknologi baru yang dikembangkan oleh suatu perusahaan, maka hal ini dapat menyebabkan menurunnya 
ketertarikan konsumen terhadap teknologi ataupun layanan yang perusahaan ciptakan tersebut. Adapun hal ini berikutnya dapat menurunkan (atau bahkan menghilangkan) intensi konsumen di dalam menggunakan suatu teknologi ataupun sistem baru yang telah diciptakan oleh pihak perusahaan.

Penelitian sebelumnya yang dilakukan oleh Alshurideh et al., (2021) menemukan bahwa perceived security, perceived privacy, perceived ease of use, trust serta perceived usefulness sebagai beberapa faktor yang mampu mendorong konsumen ataupun masyarakat di dalam menggunakan teknologi e-payment di Uni Emirat Arab. Sementara itu, penelitian lain yang dilakukan oleh Garrouch (2021) di Arab Saudi menemukan bahwa perceived e-shopping values serta e-payment benefits sebagai 2 faktor yang mampu meningkatkan intensi masyarakat di dalam menggunakan layanan e-payment. Berdasarkan hasil penelitian sebelumnya dari kedua studi ini, maka peneliti merasa bahwa dibutuhkan studi secara lebih lanjut di dalam menemukan faktor apa sajakah yang mampu mendorong intensi masyarakat Indonesia di dalam menggunakan layanan e-payment, mengingat bahwa kedua penelitian tersebut dilakukan terhadap masyarakat di wilayah Arab serta Timur Tengah yang kemungkinan besar memiliki perbedaan karakteristik serta sikap apabila dibandingkan dengan penduduk ataupun masyarakat yang tinggal di Indonesia. Dengan demikian, maka atas dasar inilah peneliti mencoba untuk meneliti bagaimana peranan yang dimiliki oleh benefits, trust serta ease of use di dalam menentukan intensi konsumen serta masyarakan Indonesia di dalam mengadopsi serta menggunakan berbagai aplikasi ataupun layanan e-payment yang telah banyak tersedia di pasaran saat ini sebagai media ataupun alat pembayaran utama ketika konsumen akan melakukan pembayaran terhadap proses pembelian produk ataupun jasa yang sedang dilakukan.

\section{Rumusan Masalah}

Berdasarkan pada latar belakang penelitian yang telah dipaparkan secara rinci pada bagian sebelumnya, maka terdapat 3 (tiga) rumusan masalah yang ingin dikaji secara mendalam pada penelitian ini, yaitu: apakah benefits berpengaruh positif dan signifikan terhadap usage intention konsumen di dalam menggunakan layanan e-payments?; apakah trust berpengaruh positif dan signifikan terhadap usage intention konsumen di dalam menggunakan layanan e-payments?; serta apakah ease of use berpengaruh positif dan signifikan terhadap usage intention konsumen di dalam menggunakan layanan e-payments?

\section{Landasan Teori dan Hipotesis Penelitian \\ Benefits}

Teoh et al., (2013) mendefinisikan benefits sebagai berbagai keuntungan yang dapat konsumen peroleh dan rasakan ketika konsumen menggunakan suatu produk ataupun jasa yang dipasarkan ataupun ditawarkan oleh sebuah perusahaan. Selain itu, San-Martin \& Lopez-Catalan (2013) juga mendefinisikan benefits sebagai penilaian personal konsumen ketika berbagai keuntungan ataupun berbagai hal positif yang konsumen rasakan jauh lebih besar dibandingkan dengan biaya (costs) yang dikeluarkan oleh konsumen untuk memperoleh suatu produk ataupun jasa yang diinginkan oleh konsumen tersebut.

\section{Trust}

Sebagai salah satu variabel yang paling sering dibahas di dalam ranah pemasaran, trust dapat dipahami sebagai persepsi konsumen terkait dengan apakah pihak perusahaan akan melakukan berbagai hal yang telah dijanjikan sebelumnya kepada konsumen (Wilson \& Keni, 2018). Adapun dalam hal ini, trust ataupun kepercayaan baru akan terbentuk di dalam diri konsumen ketika perusahaan berhasil memberikan berbagai hal yang sebelumnya telah dijanjikan kepada 
pihak konsumen. Selain itu juga, trust juga dapat dipahami ataupun didefinisikan sebagai penilaian konsumen terkait dengan seberapa tinggi resiko yang dapat dirasakan oleh konsumen ketika konsumen akan melakukan transaksi ataupun aktivitas pembelian atas suatu produk ataupun jasa yang ditawarkan oleh suatu perusahaan (Chau \& Poon, 2003; Teoh et al., 2013; Azmi et al., 2016)

\section{Ease of Use}

Sebagai salah satu konsep yang memiliki kaitan yang cukup erat di dalam ranah teknologi, ease of use dapat didefinisikan sebagai persepsi ataupun penilaian pribadi konsumen terkait dengan sejauh mana sebuah teknologi yang diciptakan oleh suatu perusahaan dapat dipelajari serta dipahami dengan baik serta mudah oleh konsumen (Guriting \& Oly, 2006; Newman et al., 2018). Selain itu, konsepsi dasar dari ease of use ini sendiri juga dapat dipahami sebagai suatu konsep berkaitan dengan penilaian masyarakat terkait dengan seberapa cepat sebuah teknologi ataupun sistem yang baru saja digunakan dapat dipelajari serta dikuasai dengan baik oleh kelompok masyarakat ataupun konsumen tersebut (Lwoga \& Komba, 2015; Lee \& Kim, 2017; Wilson, 2019; Pipitwanichakarn \& Wongtada, 2020; Verma et al., 2020)

\section{Pengaruh Benefits terhadap Usage Intention}

Penelitian sebelumnya yang dilakukan oleh Teoh et al., (2013) menemukan bahwa Benefits yang konsumen serta masyarakat miliki terhadap suatu sistem e-payment yang dikembangkan oleh suatu perusahaan berpengaruh signifikan di dalam meningkatkan intensi masyarakat serta konsumen di dalam menggunakan layanan e-payment yang dikembangkan oleh perusahaan tersebut. Selanjutnya, penelitian lain yang dilakukan oleh Garrouch (2020) juga menemukan pengaruh signifikan yang diberikan oleh benefits terhadap intensi masyarakat ataupun konsumen di dalam menggunakan teknologi ataupun sistem tersebut. Berikutnya, Liao dan Yang (2020) juga telah menemukan adanya korelasi ataupun hubungan positif yang terbentuk antara benefits yang konsumen rasakan terhadap intensi konsumen di dalam menggunakan layanan e-payment yang tersedia. Berdasarkan pada beberapa hasil penelitian terdahulu yang telah dipaparkan ataupun disampaikan diatas, maka terdapat beberapa hipotesis yang dapat dirumuskan pada penelitian ini, yaitu:

\section{H1: Benefits berpengaruh positif dan signifikan terhadap Usage Intention}

\section{Pengaruh Trust terhadap Usage Intention}

Penelitian sebelumnya yang dilakukan oleh Phonthanukitithaworn et al., (2016) telah menemukan pengaruh positif dan signifikan yang diberikan oleh trust terhadap intensi masyarakat di dalam menggunakan suatu sistem ataupun teknologi yang dikembangkan oleh suatu perusahaan. Berikutnya, Wilson \& Keni (2018), serta Jamshidi \& Hussin (2016) juga menemukan pengaruh positif serta signifikan yang diberikan oleh trust terhadap usage intention. Hasil dari beberapa penelitian terdahulu ini sendiri menunjukan bahwa seberapa tinggi tingkat kepercayaan yang dimiliki oleh konsumen terhadap suatu sistem ataupun teknologi dapat mempengaruhi seberapa kuat intensi konsumen tersebut di dalam memutuskan untuk menggunakan suatu sistem ataupun teknologi yang diciptakan oleh suatu perusahaan. Berdasarkan pada beberapa hasil penelitian terdahulu yang telah dipaparkan ataupun disampaikan diatas, maka terdapat beberapa hipotesis yang dapat dirumuskan pada penelitian ini, yaitu:

H2: Trust berpengaruh positif dan signifikan terhadap Usage Intention 


\section{Pengaruh Ease of Use terhadap Usage Intention}

Penelitian sebelumnya yang dilakukan oleh Perry (2017) juga menemukan adanya pengaruh positif serta signifikan yang diberikan oleh ease of use terhadap attitude ataupun sikap konsumen terhadap suatu sistem ataupun aplikasi yang dikembangkan oleh perusahaan. Adapun nantinya, sikap ataupun attitude yang konsumen miliki inilah yang dapat mempengaruhi intesi konsumen untuk menggunakan suatu sistem ataupun aplikasi tertentu. Selanjutnya, penelitian lain yang dilakukan oleh Kim et al., (2016) juga menemukan pengaruh signifikan yang diberikan oleh ease of use terhadap attachment yang konsumen miliki terhadap suatu produk, jasa ataupun sistem yang diciptakan oleh suatu perusahaan. Berdasarkan hasil ini, maka dapat dipahami bahwa tingkat attachment yang tinggi inilah yang nantinya akan berpengaruh terhadap seberapa kuat intensi masyarakat ataupun konsumen di dalam menggunakan teknologi ataupun sistem tersebut. Berikutnya, penelitian sebelumnya yang dilakukan oleh Alshurideh et al., (2021) juga menemukan pengaruh positif serta signifikan yang diberikan oleh ease of use terhadap intensi konsumen di dalam menggunakan jasa e-payment yang tersedia. Berdasarkan pada beberapa hasil penelitian terdahulu yang telah dipaparkan ataupun disampaikan diatas, maka terdapat beberapa hipotesis yang dapat dirumuskan pada penelitian ini, yaitu:

\section{H3: Ease of Use berpengaruh positif dan signifikan terhadap Usage Intention}

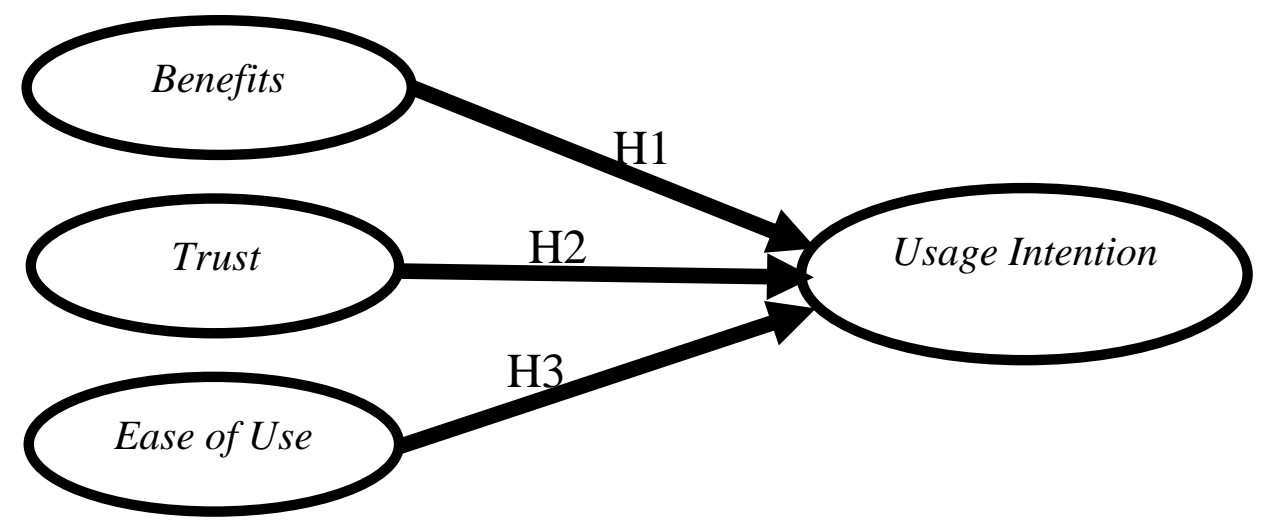

Gambar 1. Model Penelitian

Sumber: Alshurideh et al., (2021), Jamshidi \& Hussin (2016) dan Kim et al., (2016)

\section{METODE PENELITIAN}

Penelitian ini merupakan penelitian kuantitatif, yang dimana, seluruh data yang dibutuhkan untuk penelitian ini dikumpulkan dari para responden dengan menggunakan kuesioner. Adapun sebanyak 180 responden berpartisipasi di dalam penelitian ini. Setelah seluruh data dari responden dikumpulkan, maka berikutnya peneliti melakukan pengecekan serta analisa yang mendalam terhadap setiap data yang diberikan oleh para responden. Berikutnya, berdasarkan hasil pengecekan serta validasi yang telah dilakukan, maka peneliti dapat menyimpulkan bahwa seluruh data yang terkumpul merupakan data yang valid, reliabel, serta dapat digunakan dan dianalisa secara lebih lanjut di dalam penelitian ini. Selanjutnya, terkait dengan kuesioner yang digunakan pada penelitian ini, seluruh kuesioner disebarkan secara daring (online) kepada seluruh responden dengan menggunakan google forms, mengingat bahwa kondisi pandemi COVID-19 yang saat ini sedang terjadi membuat proses penyebaran kuesioner secara fisik langsung kepada para responden menjadi tidak mungkin untuk dilakukan. Adapun skala likert 5 poin digunakan dan diimplementasikan pada kuesioner yang digunakan di dalam penelitian ini. Terkait dengan skala ini, responden dapat memberikan jawaban ataupun response terhadap setiap statement ataupun pernyataan yang ada di dalam kuesioner dengan memberikan angka 
antara 1 (yang mengindikasikan bahwa responden sangat tidak setuju terhadap pernyataan tersebut), hingga 5 (yang menunjukkan bahwa responden sangat setuju terhadap pernyataan tersebut). Selanjutnya, nantinya seluruh data yang telah terisi dan terkumpul ini akan dianalisis dengan menggunakan metode PLS-SEM guna mengetahui bagaimana hubungan antar variabel yang terbentuk pada penelitian ini.

Berikutnya, terkait dengan instrument ataupun indikator yang digunakan dan diadopsi guna menjelaskan masing-masing variabel yang diteliti pada penelitian ini, sebanyak 14 indikator digunakan untuk menjelaskan seluruh variabel yang dikaji di dalam penelitian ini. Adapun sebanyak 4 indikator yang menjelaskan variabel benefits diadopsi dari Teoh et al., (2013), serta sebanyak 4 indikator yang menjelaskan variabel trust diadopsi dari Jamshidi \& Husin (2016). Berikutnya, sebanyak 3 indikator yang menjelaskan variabel ease of use diadopsi dari Kim et al., (2016) dan Wilson et al., (2021), serta sebanyak 3 indikator yang menjelaskan variabel usage intention diadopsi dari Teoh et al., (2013), Alleyne \& Lavine (2013), serta Wilson et al., (2019).

\section{HASIL DAN PEMBAHASAN}

Seluruh data yang telah terkumpul pada penelitian ini selanjutnya akan dianalisa dengan menggunakan metode PLS-SEM. Berkaitan dengan hal ini, bukan saja bahwa hasil yang diperoleh dari hasil analisis data dengan menggunakan PLS-SEM ini akan digunakan untuk menentukan bagaimana hubungan antar variabel yang terbentuk pada penelitian ini, namun juga bahwa hasil analisis yang diperoleh pada penelitian ini akan digunakan sebagai patokan di dalam menentukan apakah hipotesis-hipotesis yang diajukan pada penelitian ini ditolak atau diterima. Seluruh proses analisis data dilakukan dengan menggunakan software SmartPLS 3.3.2.

Adapun sebelum dilakukan analisis data secara mendalam terkait dengan seluruh data yang telah dikumpulkan pada penelitian ini, terlebih dahulu peneliti melakukan analisis terhadap profil dari seluruh responden yang berpartisipasi pada penelitian ini. Berdasarkan hasil analisis yang telah dilakukan terhadap profil responden, ditemukan bahwa mayoritas dari responden adalah pria $(60.55 \%)$, serta mayoritas dari para responden bekerja sebagai karyawan swasta (68.33\%). Selain itu juga, mayoritas dari responden menyatakan bahwa dalam kurun waktu sebulan, mereka cenderung menggunakan berbagai layanan e-payment yang tersedia sebanyak 3-8 kali terkait dengan aktivitas transaksi yang dilakukan $(65 \%)$.

\section{Analisis Model Pengukuran}

Di dalam melakukan analisis data dengan menggunakan metode PLS-SEM, terdapat 2 bentuk analisis yang harus dan wajib dilakukan oleh setiap peneliti, yaitu analisis model pengukuran, serta analisis model struktural. Adapun analisis model pengukuran dilakukan guna menentukan apakah memang seluruh indikator beserta variabel yang dikaji di dalam studi ini telah memenuhi seluruh persyaratan validitas serta reliabilitas yang telah ditentukan pada penelitian ini. Adapun analisis model struktural merupakan suatu tahapan ataupun proses yang dilakukan guna melihat serta menentukan pengaruh yang diberikan oleh setiap variabel terhadap variabel lainnya yang dikaji di dalam penelitian ini. Namun, analisis model strukural ini baru dapat dilakukan apabila seluruh data, indikator serta variabel yang diteliti telah memenuhi seluruh kriteria yang telah ditentukan di dalam analisis model pengukuran.

Berkaitan dengan hal ini, maka terdapat beberapa kriteria ataupun persyaratan yang harus dan wajib dipenuhi oleh seluruh indikator serta variabel agar indikator serta variabel tersebut dapat dikatakan sebagai indikator dan variabel yang valid serta reliabel. Beberapa kriteria ini sendiri 
diantaranya adalah nilai loading factor yang harus lebih tinggi dari 0.6, nilai AVE yang harus lebih tinggi dari 0.5 , nilai composite reliability yang harus lebih tinggi dari 0.7 , serta nilai korelasi antar sesama variabel yang sama harus lebih tinggi dibandingkan dengan nilai korelasi antar variabel tersebut dengan variabel lainnya (cross loadings). Adapun hasil analisis model pengukuran yang telah dilakukan pada penelitian ini ditampilkan pada tabel 1, 2 serta tabel 3 dibawah ini.

Tabel 1. Hasil Analisis Model Pengukuran - Validitas

\begin{tabular}{|c|c|c|c|c|}
\hline Indikator & Pernyataan & Variabel & $\begin{array}{l}\text { Loading } \\
\text { Factors }\end{array}$ & AVE \\
\hline BEN1 & $\begin{array}{c}\text { Membayar dengan Menggunakan Aplikasi E-Payment } \\
\text { Menghemat Waktu Saya }\end{array}$ & \multirow{4}{*}{ Benefits } & 0.693 & \multirow{4}{*}{0.563} \\
\hline BEN2 & $\begin{array}{l}\text { Melakukan Pembayaran secara Virtual (E-Payment) } \\
\text { jauh lebih Praktis dibandingkan dengan ketika } \\
\text { Melakukan Pembayaran secara Konvensional dengan } \\
\text { Uang Tunai }\end{array}$ & & 0.848 & \\
\hline BEN3 & $\begin{array}{c}\text { Saya merasa lebih mudah untuk mengatur tingkat } \\
\text { Pengeluaran saya ketika melakukan Pembayaran } \\
\text { melalui E-Payment }\end{array}$ & & 0.695 & \\
\hline BEN4 & $\begin{array}{c}\text { Melakukan pembayaran melalui Aplikasi E-Payment } \\
\text { jauh lebih Efisien dan Mudah dibandingkan dengan } \\
\text { ketika saya melakukan pembayaran dengan } \\
\text { menggunakan Uang Tunai }\end{array}$ & & 0.719 & \\
\hline TRU1 & $\begin{array}{l}\text { Saya percaya bahwa perusahaan yang mengelola } \\
\text { aplikasi E-Payment yang saya gunakan dapat menjaga } \\
\text { kerahasiaan dari seluruh data yang saya berikan }\end{array}$ & \multirow{4}{*}{ Trust } & 0.804 & \multirow{4}{*}{0.520} \\
\hline TRU2 & $\begin{array}{c}\text { Saya merasa bahwa Resiko yang saya hadapi ketika } \\
\text { menggunakan Aplikasi E-Payment jauh lebih rendah } \\
\text { dibandingkan dengan ketika saya melakukan transaksi } \\
\text { dengan Uang Tunai }\end{array}$ & & 0.765 & \\
\hline TRU3 & $\begin{array}{l}\text { Saya percaya bahwa seluruh informasi yang diberikan } \\
\text { oleh pihak perusahaan yang mengelola aplikasi E- } \\
\text { Payment yang saya gunakan merupakan Informasi yang } \\
\text { tepat }\end{array}$ & & 0.602 & \\
\hline TRU4 & $\begin{array}{l}\text { Saya percaya bahwa pihak perusahaan yang mengelola } \\
\text { aplikasi E-Payment yang saya gunakan tidak akan } \\
\text { pernah merugikan pada penggunanya }\end{array}$ & & 0.688 & \\
\hline EoU1 & $\begin{array}{l}\text { Mempelajari seluruh fitur yang ada di Aplikasi E- } \\
\text { Payment yang saya gunakan merupakan hal yang } \\
\text { mudah }\end{array}$ & \multirow{3}{*}{ Ease of Use } & 0.845 & \multirow{3}{*}{0.517} \\
\hline EoU2 & $\begin{array}{l}\text { Mudah bagi saya di dalam menggunakan Aplikasi E- } \\
\text { Payment ini secara optimal }\end{array}$ & & 0.690 & \\
\hline EoU3 & $\begin{array}{l}\text { Tidak butuh waktu lama bagi saya untuk dapat } \\
\text { memahami fungsi dari setiap fitur yang ada di dalam } \\
\text { Aplikasi E-Payment yang saya gunakan }\end{array}$ & & 0.611 & \\
\hline UI1 & $\begin{array}{l}\text { Saya akan lebih sering di dalam menggunakan Sistem } \\
\text { Pembayaran E-Payment dibandingkan dengan Sistem } \\
\text { Pembayaran secara Konvensional }\end{array}$ & \multirow{3}{*}{$\begin{array}{l}\text { Usage } \\
\text { Intention }\end{array}$} & 0.776 & \multirow{3}{*}{0.546} \\
\hline UI2 & $\begin{array}{l}\text { Saya akan berusaha untuk selalu menggunakan Aplikasi } \\
\text { E-Payment yang saya miliki di setiap aktivitas transaksi } \\
\text { yang saya gunakan }\end{array}$ & & 0.778 & \\
\hline UI3 & $\begin{array}{l}\text { Saya akan meningkatkan intensitas penggunaan } \\
\text { Aplikasi E-Payment yang saya miliki di setiap aktivitas } \\
\text { transaksi yang saya lakukan di waktu yang akan datang }\end{array}$ & & 0.654 & \\
\hline
\end{tabular}


Tabel 2. Hasil Analisis Reliabilitas

\begin{tabular}{ccc}
\hline Variabel & Nilai Composite Reliability & Kesimpulan \\
\hline Benefits & 0.793 & Reliabel \\
\hline Trust & 0.766 & Reliabel \\
\hline Ease of Use & 0.762 & Reliabel \\
\hline Usage Intention & 0.783 & Reliabel \\
\hline
\end{tabular}

Tabel 3. Hasil Analisis Cross Loadings

\begin{tabular}{ccccc}
\hline & Benefits & Ease of Use & Trust & Usage Intention \\
\hline Benefits & $\mathbf{0 . 7 4 6}$ & & & \\
\hline Ease of Use & 0.524 & $\mathbf{0 . 7 1 9}$ & & \\
\hline Trust & 0.588 & 0.526 & $\mathbf{0 . 7 2 4}$ & $\mathbf{0 . 7 3 8}$ \\
\hline Usage Intention & 0.403 & 0.542 & 0.449 & \\
\hline
\end{tabular}

Berdasarkan pada hasil analisis model pengukuran yang telah ditampilkan pada tabel 1, 2 serta tabel 3 diatas, maka dapat disimpulkan bahwa seluruh indikator serta variabel yang diteliti pada penelitian ini telah memenuhi seluruh kriteria yang harus dipenuhi di dalam analisis model pengukuran, seperti misalkan, nilai loading factors dari seluruh indikator telah melebihi 0.6, nilai composite reliability untuk setiap variabel telah melebihi 0.7 , nilai AVE untuk setiap variabel telah melebihi 0.5 , serta nilai korelasi antar sesama variabel yang sama sudah lebih tinggi dibandingkan dengan nilai korelasi antar variabel tersebut dengan variabel lainnya (cross loadings). Dengan demikian, maka dapat disimpulkan bahwa seluruh data telah memenuhi kriteria validitas dan reliabilitas yang telah ditentukan, yang dimana, hal ini mengindikasikan bahwa analisis model struktural dapat dilakukan berikutnya.

\section{Analisis Model Struktural}

Berbeda dengan analisis model pengukuran, tahapan analisis model struktural dilakukan guna menentukan serta mengetahui bagaimana korelasi ataupun hubungan yang terbentuk antar variabel yang diteliti pada penelitian ini. Nantinya, hasil akhir yang diperoleh di dalam tahapan analisis model struktural ini akan digunakan sebagai acuan guna menentukan apakah variabel yang diajukan pada penelitian ini ditolak atau diterima. Penelitian ini sendiri menggunakan alpha sebesar 5\% $(\alpha=5 \%)$. Adapun hasil analisis model struktural, beserta dengan hasil pengujian hipotesis pada penelitian ini ditampilkan pada tabel 4, 5 serta 6 dibawah ini.

Tabel 4. Hasil Pengujian $R$-Squared serta Predictive Relevance $\left(\mathrm{Q}^{2}\right)$

\begin{tabular}{ccc}
\hline Variabel & Nilai $\boldsymbol{R}$-Squared & Nilai Predictive Relevance \\
\hline Usage Intention & 0.412 & 0.158 \\
\hline
\end{tabular}

Tabel 5. Hasil Pengujian Path Coefficient

\begin{tabular}{cccc}
\hline Hubungan & Nilai t-Statistics & Nilai $\boldsymbol{P}$-Value & Kesimpulan \\
\hline Benefits $\rightarrow$ Usage Intention & 3.496 & 0.000 & Signifikan \\
\hline $\begin{array}{c}\text { Trust } \rightarrow \text { Usage Intention } \\
\text { Ease of Use } \rightarrow \text { Usage } \\
\text { Intention }\end{array}$ & 3.271 & 0.000 & Signifikan \\
\hline
\end{tabular}


Tabel 6. Hasil Pengujian Hipotesis Penelitian

\begin{tabular}{lccc}
\hline & Hipotesis & Nilai P-Value & Kesimpulan \\
\hline H1 & Benefits berpengaruh positif dan signifikan terhadap Usage Intention & 0.000 & H1 Didukung \\
\hline H2 & Trust berpengaruh positif dan signifikan terhadap Usage Intention & 0.000 & H2 Didukung \\
\hline H3 & Ease of Use berpengaruh positif dan signifikan terhadap Usage Intention & 0.000 & H3 Didukung \\
\hline
\end{tabular}

\section{PEMBAHASAN}

Data yang ditampilkan pada tabel 4, 5 serta 6 diatas menunjukkan hasil analisis model struktural yang telah dilakukan pada penelitian ini. Data r-squared yang ditampilkan pada tabel 4 menunjukkan persentase pengaruh yang diberikan oleh seluruh variabel independen terhadap variabel dependen yang dikaji pada studi ini. Berdasarkan hasil analisis data, maka diperoleh bahwa variabel usage intention memiliki nilai $r$-squared sebesar 0.412. Berdasarkan pada hasil ini, maka peneliti dapat menyimpulkan bahwa ketiga variabel independen, yaitu benefits, trust serta ease of use, mampu memberikan besaran pengaruh sebesar $41.2 \%$ di dalam menjelaskan variabel usage intention. Adapun sisanya, yaitu sebesar 58.8\%, dipengaruhi oleh variabelvariabel lainnya yang tidak diteliti di dalam penelitian ini. Selanjutnya, berdasarkan data hasil analisis predictive relevance yang ditampilkan pada tabel 4, diperoleh hasil nilai predictive relevance dari variabel usage intention sebesar 0.158 . Berkaitan dengan hasil yang diperoleh ini, dikarenakan angka predictive relevance ini berada lebih tinggi dari 0, maka dapat disimpulkan bahwa seluruh variabel di dalam penelitian ini dapat memprediksi model dengan baik.

Berikutnya, berdasarkan pada hasil analisis model struktural yang telah ditampilkan pada tabel 5 serta 6 diatas, maka dapat disimpulkan bahwa seluruh hipotesis yang diajukan di dalam penelitian ini didukung, yang dimana, dengan demikian dapat disimpulkan bahwa Benefits, Trust serta Ease of Use masing-masing memiliki berpengaruh positif dan signifikan di dalam meningkatkan serta mempengaruhi intensi konsumen serta masyarakat Indonesia di dalam menggunakan suatu layanan ataupun sistem e-payment yang tersedia di Indonesia. Berkaitan dengan hal ini, maka dapat dipahami bahwa berbagai keuntungan ataupun keunggulan yang dapat dirasakan serta diperoleh konsumen ketika menggunakan suatu sistem ataupun aplikasi $e$ payment yang tersedia di pasaran dapat secara kuat menentukan seberapa besar intensi konsumen untuk mau menggunakan jasa ataupun aplikasi e-payment yang dikelola dan diciptakan oleh suatu perusahaan. Hal ini dikarenakan ketika konsumen merasa bahwa tidak ada keuntungan khusus yang dapat dirasakan dari penggunaan berbagai aplikasi e-payment ini, maka besar kemungkinan bahwa konsumen akan cenderung lebih tertarik untuk melakukan pembayaran secara tradisional dengan uang tunai dibandingkan dengan menggunakan layanan e-payment ini.

Selain itu juga, berdasarkan hasil analisis data yang telah dilakukan, ditemukan juga bahwa selain benefits, trust serta ease of use juga ditemukan berpengaruh positif dan signifikan di dalam mempengaruhi intensi konsumen serta masyarakat Indonesia di dalam menggunakan berbagai layanan ataupun aplikasi e-payment yang tersedia. Hasil yang diperoleh pada penelitian ini pun sejalan dengan hasil studi sebelumnya yang dilakukan oleh Wilson (2019), Alshurideh et al., (2021) serta Garrouch (2021) yang juga menemukan pengaruh signifikan dan positif yang diberikan oleh benefits, trust serta ease of use terhadap intensi masyarakat untuk mengadopsi ataupun menggunakan suatu sistem, layanan ataupun teknologi baru yang dikembangkan oleh suatu perusahaan. Berdasarkan pada hasil analisis data yang diperoleh ini, maka dapat dipahami 
bahwa tingkat kepercayaan yang konsumen miliki terhadap perusahaan yang mengelola serta menciptakan aplikasi e-payment di Indonesia ini berperan penting dan signifikan di dalam menentukan sejauh mana konsumen akan mengadopsi ataupun menggunakan layanan e-payment yang tersedia. Keyakinan konsumen bahwa seluruh data yang diberikan kepada pihak perusahaan tidak akan disalahgunakan ataupun disebarluaskan secara tidak bertanggung jawab oleh pihak perusahaan inilah yang nantinya dapat menentukan apakah pada akhirnya konsumen akan menggunakan aplikasi ataupun layanan e-payment yang ditawarkan oleh perusahaan tersebut atau tidak. Selain itu juga, persepsi konsumen terkait dengan seberapa mudah dan seberapa cepat seorang konsumen dapat mempelajari serta menguasai sistem ataupun aplikasi $e$ payment yang ada juga dapat menentukan seberapa tinggi intensi ataupun niat yang konsumen miliki di dalam mengadopsi ataupun menggunakan layanan e-payment yang dikelola dan diciptakan oleh suatu perusahaan.

\section{KESIMPULAN DAN SARAN}

Penelitian ini dilakukan guna mengetahui bagaimana dampak ataupun pengaruh yang dimiliki oleh benefits, trust serta ease of use yang konsumen rasakan terhadap intensi konsumen di dalam menggunakan ataupun mengadopsi layanan e-payment yang ada di Indonesia. Adapun berdasarkan hasil analiisis data yang telah dilakukan, maka dapat disimpulkan bahwa ketiga faktor tersebut, yaitu benefits, trust serta ease of use, memiliki pengaruh yang positif dan signifikan di dalam meningkatkan intensi konsumen utnuk menggunakan serta mengadopsi layanan e-payment yang ada di Indonesia. Berkaitan dengan kesimpulan dan temuan ini, maka peneliti ingin menyarankan kepada setiap perusahaan yang saat ini berada di dalam sektor $e$ payment di Indonesia untuk dapat menciptakan serta menambahkan berbagai promosi (seperti diskon, cashback, serta bentuk strategi promosi lainnya) terkait dengan aplikasi ataupun layanan e-payment yang diciptakan oleh perusahaan tersebut. Adapun strategi promosi yang diaplikasikan oleh perusahaan ini hanya dapat dirasakan dan diperoleh konsumen apabila konsumen menggunakan aplikasi ataupun layanan e-payment yang perusahaan tersebut kembangkan. Adapun berbagai promosi yang konsumen dapat peroleh ini secara tidak langsung akan menjadi benefits ataupun keuntungan yang konsumen dapat rasakan ketika konsumen menggunakan layanan ataupun aplikasi e-payment tersebut. Berbagai keuntungan inilah yang dapat mendorong serta memperkuat intensi konsumen untuk mau menggunakan aplikasi $e$ payment yang dikembangkan oleh suatu perusahaan.

Selain itu juga, penting juga bagi setiap perusahaan yang berkecimpung di dalam sektor $e$ payment di Indonesia ini untuk dapat memastikan keamanan serta kerahasiaan dari setiap data yang dikumpulkan dari konsumen yang notabene merupakan pengguna dari aplikasi e-payment tersebut. Adapun kemampuan perusahaan di dalam memastikan bahwa seluruh data yang konsumen berikan kepada perusahaan akan terjaga secara ketat dan tidak akan tersebarluaskan ke pihak lain dapat meningkatkan kepercayaan konsumen terhadap perusahaan dan aplikasi $e$ payment tersebut. Nantinya, kepercayaan konsumen yang tinggi inilah yang dapat memperkuat intensi konsumen untuk mau menggunakan ataupun mengadopsi sistem serta aplikasi e-payment yang perusahaan tersebut kembangkan. Selanjutnya, penting juga bagi perusahaan di dalam memastikan bahwa seluruh sistem ataupun fitur yang ada di dalam aplikasi e-payment yang dikembangkan merupakan fitur-fitur yang mudah dipelajari oleh seluruh masyarakat, yang dimana, ketika masyarakat ataupun konsumen berasumsi serta menilai bahwa mudah bagi masyarakat untuk dapat mempelajari serta menguasai seluruh fitur ataupun sistem yang ada di dalam aplikasi ataupun layanan e-payment tersebut, maka baik secara langsung ataupun tidak langsung, hal ini dapat meningkatkan intensi konsumen serta masyarakat untuk mau 
menggunakan layanan e-payment tersebut sebagai media pembayaran utama yang dipilih oleh konsumen.

Selanjutnya, meskipun penelitian ini dilakukan secara mendalam, namun terdapat beberapa keterbatasan yang muncul pada penelitian ini. Pertama, penelitian ini hanya meneliti 1 sektor saja, yaitu sektor e-payment. Dengan demikian maka dapat dipahami bahwa hasil analisis data serta kesimpulan yang dihasilkan dari penelitian ini tidak dapat secara optimal di-generalisasi ke sektor ataupun industri lainnya. Dengan demikian, maka peneliti ingin menyarankan kepada para peneliti lainnya untuk dapat mengembangkan model serta topik dari penelitian ini dengan cara meneliti ataupun menguji kembali model penelitian yang dirancang pada studi ini ke dalam sektor ataupun industri lainnya. Selain itu juga, penelitian ini hanya memasukkan variabel benefits, trust serta ease of use sebagai 3 variabel yang dapat mempengaruhi intensi masyarakat untuk menggunakan suatu sistem ataupun layanan e-payment yang ada, yang dimana, peneliti meyakini bahwa masih ada banyak variabel lainnya yang juga dapat mempengaruhi intensi masyarakat Indonesia di dalam menggunakan suatu sistem ataupun layanan e-payment. Dengan demikian, maka penelitian menyarankan kepada para peneliti berikutnya untuk dapat menambahkan beberapa variabel lainnya yang diprediksi dapat mempengaruhi intensi masyarakat untuk menggunakan suatu sistem ataupun layanan e-payment guna mengembangkan serta meningkatkan variabilitas dari model penelitian yang dirancang pada penelitian ini.

\section{REFERENSI}

Alleyne, P. dan Lavine, M. (2013). Factors influencing accountants' behavioural intentions to use and actual usage of enterprise resource planning systems in a global development agency", Journal of Financial Reporting and Accounting, 11(2), 179-200. https://doi.org/10.1108/JFRA-11-2011-0017

Alshurideh, M.T., Al Kurdi, B., Masa'deh, R. and Salloum, S.A. (2021), "The moderation effect of gender on accepting electronic payment technology: a study on United Arab Emirates consumers", Review of International Business and Strategy, Vol. ahead-of-print No. ahead-of-print. https://doi.org/10.1108/RIBS-08-2020-0102

Azmi, A., Ang, Y.D. dan Talib, S.A. (2016), "Trust and justice in the adoption of a welfare $e$ payment system", Transforming Government: People, Process and Policy, 10(3), 391-410. https://doi.org/10.1108/TG-09-2015-0037

Chau, P. dan Poon, S. (2003), "Octopus: an e-cash payment system success story", Communications of the ACM, 46(9), 129-133

Garrouch, K.F. (2021), "Explaining the comparative perception of e-payment: role of e-shopping value, e-payment benefits and Islamic compliance", Journal of Islamic Marketing, Vol. ahead-of-print No. ahead-of-print. https://doi.org/10.1108/JIMA-08-2020-0240

Guriting, P. dan Oly Ndubisi, N. (2006), "Borneo online banking: evaluating customer perceptions and behavioural intention", Management Research News, 29(1/2), 6-15. https://doi.org/10.1108/01409170610645402

Indonesian E-wallet Race 2020 - GoPay, OVO, DANA, or LinkAja. (2020, May 11). Retrieved May 17, 2021, from https://m2insights.com/the-2020-indonesian-ewallet-race/

Jamshidi, D. dan Hussin, N. (2016), "Forecasting patronage factors of Islamic credit card as a new e-commerce banking service: An integration of TAM with perceived religiosity and trust", Journal of Islamic Marketing, 7(4), 378-404. https://doi.org/10.1108/JIMA-07$\underline{2014-0050}$ 
Kim, M.J., Kim, W.G., Kim, J.M. dan Kim, C. (2016), "Does knowledge matter to seniors' usage of mobile devices? Focusing on motivation and attachment", International Journal of Contemporary Hospitality Management, 28(8), 1702-1727. https://doi.org/10.1108/IJCHM-01-2015-0031

Lee, S. and Kim, B.G. (2017), "The impact of qualities of social network service on the continuance usage intention", Management Decision, 55(4), 701-729. https://doi.org/10.1108/MD-10-2016-0731

Liao, S.H. and Yang, L.L. (2020), "Mobile payment and online to offline retail business models", Journal of Retailing and Consumer Services, Vol. 57, doi: 10.1016/j.jretconser.2020.102230

Lwoga, E.T. and Komba, M. (2015). Antecedents of continued usage intentions of web-based learning management system in Tanzania, Education + Training, 57(7), 738-756. https://doi.org/10.1108/ET-02-2014-0014

Ming-Yen Teoh, W., Choy Chong, S., Lin, B. dan Wei Chua, J. (2013), "Factors affecting consumers' perception of electronic payment: an empirical analysis", Internet Research, 23(4), 465-485. https://doi.org/10.1108/IntR-09-2012-0199

Newman, C.L., Wachter, K. dan White, A. (2018), "Bricks or clicks? Understanding consumer usage of retail mobile apps", Journal of Services Marketing, 32(2), 211-222. https://doi.org/10.1108/JSM-08-2016-0289

Perry, A. (2017), "Factors comprehensively influencing acceptance of 3D-printed apparel", Journal of Fashion Marketing and Management, 21(2), 219-234. https://doi.org/10.1108/JFMM-03-2016-0028

Phonthanukitithaworn, C., Sellitto, C. dan Fong, M.W.L. (2016), "An investigation of mobile payment (m-payment) services in Thailand", Asia-Pacific Journal of Business Administration, 8(1), 37-54. https://doi.org/10.1108/APJBA-10-2014-0119

Pipitwanichakarn, T. dan Wongtada, N. (2020), "The role online review on mobile commerce adoption: an inclusive growth context", Journal of Asia Business Studies, 14(5), 759-778. https://doi.org/10.1108/JABS-02-2019-0060

Putra, I.G.W.S.C. (2021). Pengaruh Product Usability Dan Cashback Promotion Terhadap Brand Loyalty Layanan Digital Wallet Di Indonesia, Bisma: Jurnal Manajemen, 7(1), 11-19. http://dx.doi.org/10.23887/bjm.v7i1.28413

San-Martin, S. dan Lopez-Catalan, B. (2013), "How can a mobile vendor get satisfied customers?", Industrial Management and Data Systems, 113(2), 156-170

Tren Perkembangan Online Payment di Indonesia. (2020, July 10). https://midtrans.com/id/blog/tren-perkembangan-online-payment-di-indonesia.

Verma, S., Chaurasia, S.S. and Bhattacharyya, S.S. (2020), "The effect of government regulations on continuance intention of in-store proximity mobile payment services", International Journal of Bank Marketing, 38(1), 34-62. https://doi.org/10.1108/IJBM-10$\underline{2018-0279}$

Wilson, N. (2019). The Impact of Perceived Usefulness and Perceived Ease-of-Use toward Repurchase Intention in the Indonesian E-Commerce Industry, Jurnal Manajemen Indonesia. 19(3), 241-249. https://doi.org/10.25124/jmi.v19i3.2412

Wilson, N., Alvita, M., dan Wibisono, J. (2021). The Effect of Perceived Ease of Use and Perceived Security Toward Satisfaction and Repurchase Intention, Jurnal Muara Ilmu Ekonomi dan Bisnis, 5(1), 144-159. http://dx.doi.org/10.24912/jmieb.v5i1.10489 
Wilson, N., dan Keni, K. (2018). Pengaruh Website Design Quality dan Kualitas Jasa Terhadap Repurchase Intention: Variabel Trust Sebagai Variabel Mediasi, Jurnal Manajemen dan Pemasaran Jasa, 11(2), 291- 310. http://dx.doi.org/10.25105/jmpj.v11i2.3006

Wilson, N., Keni, K., dan Tan, P.H.P. (2019). The Effect of Website Design Quality and Service Quality on Repurchase Intention in the E-commerce Industry: A Cross-Continental Analysis, Gadjah Mada International Journal of Business, 21(2), 187-222. https://doi.org/10.22146/gamaijb.33665 